\title{
Acknowledgements
}

The authors are thankful to Dr. J.R.B. Alfred, Director, Zoological

\section{BUTTERFLIES OF PENCH TIGER RESERVE, MADHYA PRADESH}

\author{
K. Chandra ${ }^{1}$, L.K. Chaudhary ${ }^{2}$, R.K. Singh ${ }^{1}$ and M.L. \\ Koshta $^{1}$ \\ ${ }^{1}$ Zoological Survey of India, Central Regional Station, 424, New \\ Adarsh Colony, Jabalpur, Madhya Pradesh 482002, India. \\ ${ }^{2}$ Pench Tiger Reserve, Seoni, Madhya Pradesh, India.
}

Pench Tiger Reserve is one among the five declared Tiger Reserves in Madhya Pradesh. It provides protected habitat to diverse forms of plants and animals. The Tiger Reserve derives its name from Pench river, which flows through it. It has a total area of $757.907 \mathrm{sq} \mathrm{km}$ traversing the Seoni and Chhindwara districts and falls between the longitude $79^{\circ} 9^{\prime}$ to $79^{\circ} 22^{\prime} \mathrm{E}$ and latitude $21^{\circ} 38^{\prime}$ to $21^{\circ} 50^{\prime} 30^{\prime \prime} \mathrm{N}$. It comprises the Pench Sanctuary, notified in the year 1977, and the Pench National Park, notified in the year 1983. These two were brought under Project Tiger, in the year 1992 .

As per the available literature and information in the draft Management Plan of the Pench Tiger Reserve, almost nothing is known about the insects occurring in the Pench Tiger Reserve (PTR), Seoni. Insects represent more than $70 \%$ of the fauna in a terrestrial ecosystem and also play an important role in food chain for the natural balance. A systematic study of invertebrates particularly butterflies has not been carried out from most of the wildlife reserves in Madhya Pradesh including PTR. A consultancy service to conduct the faunal survey in seven sites has been assigned to the Zoological Survey of India under the GEF sponsored "India Eco-development project". PTR is one of the seven sites of this ambitious project that has been under implementation since the year 1997.

The study on faunal diversity of PTR has commenced from May 2001, and the samples of almost all groups of insects were collected during May-July 2001. More than 2000 insects of different groups were collected from more than 20 localities which included 119 specimens of butterflies. The butterflies represented 38 species in eight families (Table 1). Study on their abubdance showed that 11 species were common and 13 species very common. Whereas 14 species were recorded to be rare in PTR. All 38 species are first records from PTR. The common names are according to Evans (1932) and Varshney (1983). The recent names are after Varshney $(1993,1994)$.
Survey of India, Kolkata for providing the laboratory facilities and encouragements. Thanks are also due to Shri R.G. Soni, Field Director and Conservator of Forests, Pench Tiger Reserve, Seoni for the financial and logistic support rendered during the survey of PTR.

\section{References}

Evans, W.H. (1932). The identification of Indian Butterflies. Bombay Natural History Society, Bombay, 455pp.

Talbot, G. (1939). The Fauna of British India including Ceylon and Burma. Butterflies Vol. 1. Taylor and Francis, London. Reprinted edition by Today and Tomorrow's Printers and Publishers, New Delhi, 600pp. Talbot, G. (1947). The Fauna of British India, including Ceylon and Bunna. Butterflies Vol. 11. Taylor and Francis, London. Reprinted edition by Today and Tomorrow's Printers and Publishers, New Delhi, 506pp. Varshney, R.K. (1983). Index Rhopalocera indica Part II. Common names of butterflies from India and neighbouring countries. Records of the Zoological Survey of India. Occasional Paper, No. 47: 1-49.

Varshney, R.K. (1993). Index Rhopalocera indica, part III, Genera of Butterflies from India and neighbouring countries (Lepidoptera): (A) Papilionidae, Pieridae and Danaidae). Oriental Insects, 27: 347-372.

Varshney, R.K.(1994). Index Rhopalocera indica, part III, Genera of Butterflies from India and neighbouring countries [Lepidoptera: (B) Satyridae, Nymphalidae, Libytheidae and Riodinidae].Oriental Insects, 28: 151-198.

Wynter-Blyth, M.A, (1957). Butterflies of the Indian Region. Bombay Natural History Society, Bombay, 523pp.+72pls.

Table 1. List of number of genera and species in different families of butterflies occuring in Pench Tiger Reserve

\begin{tabular}{lll}
\hline Family & Genera & Species \\
\hline Papilioniade & 4 & 5 \\
Pieridae & 4 & 7 \\
Danaidae & 3 & 4 \\
Satyride & 3 & 3 \\
Nymphalidae & 5 & 10 \\
Acraeidae & 1 & 1 \\
Lycaenidae & 6 & 6 \\
Hesperiidae & 2 & 2 \\
\hline
\end{tabular}


Table 2. List of butterflies from Pench Tiger Reserve

\begin{tabular}{|c|c|c|}
\hline Scientific name & Common name & Status \\
\hline \multicolumn{3}{|l|}{ Papilionidae } \\
\hline Pathysa nomius nomius Eper, 1785 & Spot Swordtail & $\mathrm{C}$ \\
\hline Papilio demoleus demoleus Linn.,1758 & Lime Butterfly & VC \\
\hline Papilio polytes romulus Cramer, 1775 & Common Mormon & VC \\
\hline Pachliopta hector Linn., 1758 & Crimson Rose & $\mathrm{R}$ \\
\hline Chilasa clytia clytia Linn., 1758 & Common Mime & $\mathrm{R}$ \\
\hline \multicolumn{3}{|l|}{ Pieride } \\
\hline 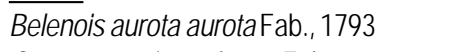 & Pioneer & $\mathrm{R}$ \\
\hline Ceporna nerissa phryne Fab., 1775 & Common Gull & $\mathrm{R}$ \\
\hline Catopsilia pomona Fab.,1775 & Lemon Emigrant & VC \\
\hline Catopsilia pyranthe pyranthe Linn.,1758 & Mottled Emigrant & VC \\
\hline Earema brigittarubella Wallace,1867 & Small Grass Yellow & $\mathrm{C}$ \\
\hline Earema laeta laeta Boisduvanil,1836 & Spotless Grass yellow & VC \\
\hline Earema hecabesimulata Moore, 1881 & Common Grass Yellow & VC \\
\hline \multicolumn{3}{|l|}{ Danaidae } \\
\hline Danaus chrysippus Linn., 1758 & Plain Tiger & VC \\
\hline Danaus genutia Cramer, 1779 & Common Tiger & VC \\
\hline Tirumala limniace leopards Butler, 1866 & Blue Tiger & $\mathrm{C}$ \\
\hline Euploea core core Cramer, 1780 & Common Indian Crow & $\mathrm{C}$ \\
\hline \multicolumn{3}{|l|}{ Satyride } \\
\hline Melanitis leda ismene Cramer, 1775 & Common Evening Brown & $\mathrm{C}$ \\
\hline Mycalesis mineus Linn., 1767 & Dark-Brand Bushbrown & $\mathrm{R}$ \\
\hline Ypthima asterope Klug, 1832 & Common Three-ring & $\mathrm{C}$ \\
\hline \multicolumn{3}{|l|}{ Nymphalidae } \\
\hline $\begin{array}{l}\text { Phalanta phalantha phalantha } \\
\text { Drury, } 1770\end{array}$ & Common Leopard & $\mathrm{C}$ \\
\hline Cynthia cardui Linn.,1758 & Painted Lady & $\mathrm{R}$ \\
\hline Junonia almana almana Linn., 1758 & Peacock Pansy & $\mathrm{R}$ \\
\hline Junonia atlites Linn.,1763 & Grey Pansy & $\mathrm{R}$ \\
\hline Junonia hierta hierta Fab., 1798 & Yellow Pansy & $\mathrm{R}$ \\
\hline Junonia lemonias vaisya & Lemon Pansy & $\mathrm{C}$ \\
\hline \multicolumn{3}{|l|}{ Fruhstorfer, 1912} \\
\hline Junonia orithya swinhoeiButler, 1885 & Blue Pansy & $\mathrm{R}$ \\
\hline Hypolimnas bolina Linn.,1758 & Great Eggfly & $\mathrm{R}$ \\
\hline Hypolimnas misippus Linn.,1764 & Danaid Eggfly & $\mathrm{C}$ \\
\hline Symphaedra nais Forster, 1771 & Baronet & C \\
\hline \multicolumn{3}{|l|}{ Acraeidae } \\
\hline Acraea violae Fab., 1775 & Twany Coster & VC \\
\hline \multicolumn{3}{|l|}{ Lycaenidae } \\
\hline Catochrysops starbo strabo Fab., 1793 & Forget-me-not & VC \\
\hline Castalius rosimon rosimon Fab., 1775 & Common Pierrot & $\mathrm{C}$ \\
\hline Tarucus theophrastus Fab., 1793 & Pointed Pierrot & VC \\
\hline Zizeeria gaika Trimen, 1862 & Tiny Grass Blue & VC \\
\hline Chilades pandava Horsfield, 1829 & Plains Cupied & VC \\
\hline Rapala melampus Cramer, 1781 & Small Branded Swift & $\mathrm{R}$ \\
\hline \multicolumn{3}{|l|}{ Hesperiidae } \\
\hline Pelopidas mathias Fab., 1798 & Small Branded Swift & $\mathrm{R}$ \\
\hline Telicota ancilla Herrich-Schaffer, 1869 & Pale Palm Dart & $\mathrm{R}$ \\
\hline
\end{tabular}

VC- Very Common in Pench Tiger Reserve, C- Common in Pench Tiger Reserve, R- Rare in Pench Tiger Reserve.

\section{BUTTERFLIES OF KALATOP -KHAJJIAR WILDLIFE SANCTUARY, HIMACHAL PRADESH}

\author{
M.S. Thakur ${ }^{1}$, H.S. Mehta ${ }^{1}$ and V.K. Mattu ${ }^{2}$ \\ ${ }^{1}$ High Altitude Zoology Field Station, Zoological Survey of India, \\ Saproon, Solan, Himachal Pradesh 173211, India. \\ ${ }^{2}$ Department of Life Sciences, Himachal Pradesh University, \\ Summer Hill, Shimla, Himachal Pradesh 171005, India.
}

Kalatop-Khajjiar Wildlife Sanctuary in Himachal Pradesh is situated at an altitude of $1185-2768 \mathrm{~m}$. It extends between $31^{0} 31^{\prime}-$ $32^{\circ} 37^{\prime} \mathrm{N}$ and $75^{\circ} 58^{\prime}-76^{\circ} 7^{\prime} \mathrm{E}$ in the foothills of Kailash Parvat (western Himalaya). The Sanctuary is spread over $20.69 \mathrm{~km}^{2}$ area, and lies in the catchment of river Ravi. The area contains a good number of coniferous and oak forest patches. A lovely bowl-shaped meadow at Khajjiar, with a lake and a floating island is a popular tourist spot. The Sanctuary has alluvial soil that is a substrate to plants like mixed Blue Pine and Cedrus deodara, Green Oak and Rhododendron arboreum. Average rainfall is $2647.68 \mathrm{~mm}$ and average snowfall is $672.3 \mathrm{~mm}$. Temperature ranges between between $-10^{\circ} \mathrm{C}$ in winter and $35^{\circ} \mathrm{C}$ in summer.

Kalatop-Khajjiar Wildlife Sanctuary has no consolidated and authentic record of butterflies. A number of surveys were made from September 2000 to August 2001, which resulted in the enumeration of 49 species belonging to 38 genera in nine families (Table 1). After refering publications of butterflies of the region (Philip de Rhe, 1936; Wynter-Blyth, 1940, 1945, 1946, 1957; Mani, 1986), Lethe scanda Moore, Ypthima lycus deN. and Ypthima ceylonica hubneri Kirby turned out to be first records for Himachal Pradesh.

\section{Acknowledgements}

We are grateful to Dr. J.R.B. Alfred, Director, Zoological Survey of India, Kolkata for laboratory facilities; Dr. G..S. Arora for confirming the status of a few species; Dr. R.M. Sharma, Scientist C, HAZFS, ZSI Solan for various help and preparation of this manuscript. Our sincere thanks are also to the staff of this station for their cooperation. Our thanks are also to Sh. Alok Nagar, DFO, Wildlife Division, Chamba for permission and providing various facilities during surveys.
Manuscript received 16 February 2001

Accepted for publication 21 August 2002 